\title{
POATE FI ECHIVALAT GOLEMUL DIN PSALMUL 138, 16 CU ISAIA 53, 2? O TIPOLOGIE HRISTOLOGICĂ EMBRIONARĂ A VECHIULUI TESTAMENT ${ }^{1}$
}

\author{
Pr. Claudiu Ioan COMAN
}

\begin{abstract}
Starting from the text Ps 138, 16, but also from a prophetic text, Is 53, 2, we analyzed from the biblical point of view some aspects in relation to a possible equivalence between a poetic text and one with a pronounced prophetic character. The red thread that unites the two texts is, in practice, a messianic, revelatory idea, about which it offers testimony and other places of Scripture. Following the analysis of the most important parts of the Messiah, I intend to deduce that the biblical testimonies speak of what Jesus will be: from the body of the Virgin Mary God will appear as a human being, coming into the world he created to save her.
\end{abstract}

Keywords: revelation, prophetic texts, golem, morphe, hapax legomenon.

Unul dintre cuvintele rare, „hapax legomenon” din Cartea Psalmilor este termenul golem, care apare în Vechiul Testament doar o singură dată, în Psalmi 139, 16 (138, 16, cf. LXX). Consider că înainte de abordarea subiectului sunt necesare câteva lămuriri preliminare în care să ofer câteva informații cu caracter general despre Cartea Psalmilor (Sepher Tehilim).

Importanța psalmilor este dovedită de Sfântul Evanghelist Luca atunci când, spre finalul celei de-a treia evanghelii, istorisește o întâlnire atipică dintre Iisus Cel înviat, cu doi dintre ucenicii Săi, care se deplasau spre localitatea Emaus. În timpul călătoriei și la scurtă vreme după Răstignirea Domnului, un Necunoscut îi întâlnește și îi abordează într-un mod surprinzător pentru ei: Ce sunt

${ }^{1}$ Inițial, acest studiu a fost titlul unei Conferințe pe care am susținut-o la Universitatea "Alexandru Ioan Cuza" din Iași în cadrul Serilor de filologie și hermeneutică biblică. Aici se află doar prima parte a textului respectivei comunicări. 
cuvintele acestea pe care le schimbați între voi pe drum? Ei s-au oprit triști (Luca 24, 18).

Unul dintre ucenici, identificat de evanghelist a fi Cleopa, îi răspunde ironic: Numai tu ești străin în Ierusalim și nu știi cele petrecute în zilele acestea? (Luca 24, 18). Urmează o scurtă descriere a lui Iisus Nazarineanul, un fel de portret schițat de ucenicul care-L credea profet puternic în faptă și în cuvânt înaintea lui Dumnezeu și a întregului popor (Luca 24, 19). Neliniștea celui care relatează se amplifică: toți credeau că El, Iisus, e Cel ce avea să izbăvească pe Israel (din robia politică, probabil), însă marele Eliberator fusese răstignit, murise pe cruce și apoi fusese înmormântat și, de la nefericitul și mirabilul eveniment abia trecuseră trei zile. Însă evenimentele de după erau ciudate: unele femei au mers la mormânt și au văzut uimite că mormântul era gol. Trupul lui Iisus era de negăsit. Mai mult, atunci când ele credeau că Invățătorul lor eșuase, au avut parte de o anghelofanie: niște îngeri le-au spus că Iisus este viu! Faptul părea să se confirme: unii ucenici, auzind, au mers la mormânt și s-au convins că femeile nu mințeau. Problema era aceea că nu L-au văzut pe Iisus nicăieri. Trupul dispăruse, zvonul că era viu circula cu repeziciune, dar El rămânea oarecum ascuns privirilor curioase.

Important este, însă, răspunsul oferit de Străin: toate acestea trebuiau să se întâmple, pentru că așa zice Scriptura! Străinul începe să le facă o exegeză a textelor mesianice celor doi, argumentându-le că acesta este destinul mundan al lui Mesia și că, evenimentele desfăşurate la Ierusalim au fost o împlinire a textelor din Legea lui Moise, din profeți și din psalmi.

Întrebarea este: de ce psalmii sunt, în ochii Străinului (despre care știm acum că era Iisus Însuși) de o importanță egală cu Tora sau cu textele profeților?

Firește, istoria exegezei biblice va oferi răspunsuri satisfăcătoare. Aici mă limitez doar la hermeneutica lui Léopold Sabourin, care citează un comentariu din ediția critică a Scripturii, La Bible de Jérusalem, când afirmă că: „Psalmii erau importanți pentru hristologie deoarece aceștia erau reprezentativi pentru cea de-a treia parte a Bibliei, în care «Psaltirea constituie prima Carte din listă»"².

${ }^{2}$ Cf. Léopold Sabourin, Evanghelia lui Luca. Introducere și comentariu, traducere din limba franceză de Lucian-Iulian Diac, Editura Sapientia, Iași, 2015, p. 403. 
În privinţa împărţirii psalmilor, Textul Masoretic diferă de cel al Septuagintei prin aceea că, „TM împarte Psalmul 9 în două, rezultând Psalmii 9 și 10, în timp ce $L X X$ păstrează doar un psalm. Decalajul produs suferă o nouă modificare atunci când $L X X$ alcătuiește Psalmul 113 din doi psalmi (114-115 din TM). In schimb, Psalmul 116 din TM este împărțit în două de $L X X$, revenind din nou, prin aceasta, la decalajul de un psalm după modificarea produsă la psalmii anteriori. Spre sfârșitul Psaltirii, Psalmul 117 din TM este, la rândul lui, împărțit de LXX în două (146-147), astfel încât ultimii psalmi își corespund în numerotare" ${ }^{\prime 3}$.

Se impune aici semnalarea faptului că, atât Sabourin, cât și editorii $B J$ ignoră să menționeze măsura în care textele Scripturii erau importante pentru epoca în care a trăit lisus Hristos.

Suntem, din punct de vedere temporal, departe de perioada în care au fost scrise textele care alcătuiesc canonul biblic. Iisus, însă, se adresase unor contemporani care, cu toată ,,simplitatea intelectuală" puteau înțelege mai bine decât noi mesajul, mai ales că acea hermeneutică despre care vorbeam adineaori, așa cum ar fi logic, era simplă.

Un exemplu în acest sens este cel al profetului Maleahi. În Maleahi 3, 16 scrie: ...Și Domnul a luat aminte și a ascultat; o carte de aducere aminte a fost scrisă înaintea Lui spre binele celor ce se tem de El și caută scăpare în numele Lui. După cum bine observă Pieter A. Verhoff, „forma de nifal a verbului kātāab, «a fost scrisă», sugerează ideea că Domnul, ca rege, are un funcționar al Său responsabil cu consemnările în «cartea de aducere aminte»" ${ }^{4}$. Ceea ce este important de semnalat, potrivit lui Verhoff, e că ,termenul ebraic «zikkaron», «aducere aminte», nu se referă doar la lucruri din trecut care trebuie amintite. El sugerează și ideea faptelor din prezent legate de aducerea aminte. Botterweck afirmă corect: «Aducerea aminte a lui Dumnezeu este întotdeauna un eveniment creator și o actualizare activă». În «cartea de aducere aminte» sunt scrise lucrurile de care El dorește să-și aducă aminte și în legătură cu care vrea să facă ceva" ${ }^{5}$.

${ }^{3}$ Pr. prof. univ. dr. Ioan Chirilă (coord.), Introducere în Vechiul Testament. Manual pentru Facultățile de Teologie Ortodoxă, Editura Basilica, București, 2018, pp. 438-439.

${ }^{4}$ Pieter A. Verhoef, Hagai și Maleahi, în seria CEXEL, traducere de Daniela Rusu și Daniel Rusu, Editura Logos, Cluj-Napoca, 2012, p. 376.

${ }^{5}$ Ibidem, p. 376. 
Cele de mai sus sunt întărite de o serie de texte descoperite în Orientul Apropiat, dar și în textele veterotestamentare. Sunt, din nou, excelente două exemple.

În Imn către Hamu, persoana în suferință se plânge: „Viața mea este irosită, o, tu, cel care ții socoteala universului'”' .

Mai apropiat de ideea generală a acestui studiu este textul unei scrisori babiloniene antice care arată că „un destin favorabil era decretat pentru autorul scrisorii încă de când era în pântecele mamei sale" ${ }^{\prime 7}$.

Exemplul „clasic", biblic însă este cel din Exod 32, 32-34, unde Moise își exprimă dorința de a fi șters din cartea celor vii, ceea ce denotă „,o acțiune care ar fi avut ca sfârșit moartea sa" ${ }^{\prime 8}$. Răspunsul ferm al lui YHWH este că doar păcătosul va fi șters din cartea Sa.

Nu este de mirare, așadar, că lisus apelează la texte pentru a argumenta că destinul său era acela care se confunda cu suferința salvifică.

După acest scurt excurs argumentativ preliminar asupra valorii Psalmilor, dedusă din utilizarea metodei comparative, mă voi referi, în cele ce urmează, la o altă problemă, esențială pentru hermeneutică, cea a textului în sine. Am câteva variante pentru Psalmi 139, 16 (138, 16 LXX): ebraică, greacă, King James, și două autohtone: una ortodoxă, cealaltă catolică9.

Prima variantă, cea de bază pentru acest studiu, este Biblia Hebraica Stuttgartensia ${ }^{10}$ : gā-lə-mî rā-' $\bar{u}$ 'ê-ne-k̄ā, wə-'al-sip̄-rə-k̄ā kullām yik-kā-têe-b̄ū yā-mîm yuṣ-ṣā-rū; [wə-lō (wə-lōw e-ḥād bā-hem.

Ceea ce mă interesează aici, în varianta ebraică a textului, este

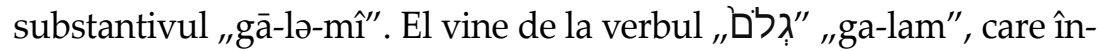
seamnă a înveli, a plia, a împacheta. La fel ca substantivul "gā-lə-mî”,

${ }^{6} \mathrm{Cf}$. John H. Walton, Victor H. Matthews, Mark W. Chavalas, Comentariu cultural-istoric al Vechiului Testament, traducere de Silviu Tatu, Luca Crețan, Romana Cuculea, Editura Casa Cărții, Oradea, 2014, p. 599.

${ }^{7}$ Ibidem, p. 599.

${ }^{8}$ Ibidem, p. 871.

${ }^{9} \hat{\text { In }}$ proiectul grandios MLD, în volumul dedicat psalmilor, aici nu este nici o referire, nici o aluzie, nici un comentariu cu privire la v. 16. A se vedea: prof. dr. Al. Andriescu, prof. dr. Paul Miron (coord.), Monumenta Linguae Dacoromanorum. Biblia 1688. Liber Psalmorum, Pars XI, Editura Universității „Al. I. Cuza”, Iași, 2003.

$10 * * *$, Biblia Hebraica Stuttgartensia, Deutsche Bibelgesellschaft, Stuttgart, 1990, p. 1218. 
și verbul „ga-lam" este un hapax legomenon, folosit doar într-o singură situație, în 2 Regi (4 Regi) 2, 8. Despre ce vorbește acel text? Este vorba despre despărțirea Iordanului cu ajutorul mantiei profetului Ilie care a strâns-o „,vălătuc”, adică a rulat-o, făcându-o sul, și a lovit apa cu ea. Interesantă este hermeneutica textului referitor la acțiunea profetului Ilie, asemănat cu Moise cel care a despărțit Marea Roșie, dacă privim textul din 1 Regi 19, 19-21. Acolo este descrisă acțiunea profetului prin care, aruncându-și mantia peste Elisei, cel din urmă devine succesorul său. Gestul, în sine, simboliza "trecerea puterii și a autorității slujbei acelui om"11. La fel, gestul profetului de a despărți apa cu ajutorul mantiei pe care a făcut-o sul denotă autoritatea lucrătoare a lui Dumnezeu.

Dacă luăm cele două imagini din Regi: cea a mantiei ca acoperire și cea a aceleiași mantii rulate, deci a unui obiect care prezintă interes hermeneutic pentru că este o imagine a acțiunii lui YHWH și le raportăm la v. 16 din Psalmi 139, atunci observăm că făcând o paralelă, psalmistul vorbește despre aceeași putere manifestată de YHWH, chiar în clipa când omul este la statutul de embrion în formare, deoarece acesta este sensul lui ,gā-lə-mî”", ceva nedefinit, fără o formă precisă, sau în căutarea unei forme. Este vorba despre ceva care începe să se formeze, să fie la nivel de schiță.

Însă, ca să înțelegem pe deplin rolul acestui substantiv, este necesară raportarea la noțiunile istorice. Așa cum dovedește Samuel J. Schultz ${ }^{12}$, fiecare psalm este o unitate separată, independent de ceilalți. În cazul Psalmului 139, John Phillips precizează că, deși David este considerat autor al său, unii exegeți au pus la îndoială paternitatea davidică pentru acest text ${ }^{13}$. Justificarea obiecțiilor vine în urma analizei textuale prin intermediul căreia s-au identificat o serie de expresii chaldeene, ceea ce ar dovedi că acest psalm ar fi fost scris cu mult timp după perioada în care a trăit David.

${ }^{11}$ John F. Walvoord, Roy B. Zuck (edd.), Comentariu al Vechiului Testament. O expunere a Scripturilor făcută de profesorii de la Seminarul Teologic Dallas, traducere de Octavian Verlam și Constantin Leontiuc, Editura Fundației E.B.E., Cluj-Napoca, 2010, p. 526.

${ }^{12}$ Samuel J. Schultz, Călătorie prin Vechiul Testament, Editura Cartea Creștină, Oradea, 2008, p. 358.

${ }^{13}$ John Phillips, Comentariu asupra psalmilor, vol. IV, traducere de Monica Dan, Editura Stephanus, București, 2012, p. 210. 
În colecția lui Nicodim Aghioritul și Eftimie Zigaben, referitor la acest psalm, este consemnată o interpretare a lui Teodoret al Cirului, potrivit căreia psalmul conține următoarea suprascriere: „Întru sfârșit, psalm al lui David, al lui Zaharia întru risipire”. După cum arată și autorii comentariilor finale ale textelor psalmilor din seria $M L D$, „,indicația «psalmul Zahariei întru răsipire» lipsește atât din textul masoretic, cât și din LXX. Biblia de la Blaj traduce după varianta alexandrină a Septuagintei sau după Biblia

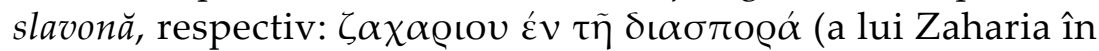
diasporă $)^{\prime \prime 14}$. La fel, Nicodim Aghioritul și Eftimie Zigaben arată că adaosul acesta este apocrif ${ }^{15}$.

Interesant este faptul că, unele medii protestante, totuși, nu contestă paternitatea davidică a acestui psalm ${ }^{16}$, ba chiar nici John Phillips nu îl contestă, dimpotrivă, zice că David ar fi putut avea legături cu Chaldeea, prin aceea că regatul său se afla la răscrucea principalelor rute comerciale ale lumii antice ${ }^{17}$. Acest din urmă autor arată chiar că patriarhul Avraam venea din Chaldeea, chaldeenii dorind să stabilească relații diplomatice cu israeliții, cel puțin pentru a asigura protecția caravanelor lor. Nici cursul introductiv în Vechiul Testament al profesorului Ioan Vasile Botiza nu clarifică noțiunile referitoare la acest psalm, afirmând doar că „,este un text postexilic, o descriere poetică a omnișcienței și a omnipotenței lui Dumnezeu" ${ }^{\prime 18}$. Dacă se extinde această presupunere de ordin lingvistic asupra influențelor chaldeene, ipoteza lansată de autorii la care m-am referit mai sus pare plauzibilă deoarece, dacă, de exemplu se fac cercetări de ordin filologic asupra Leviticului sau a 1 Regi, spusele par să se confirme.

De exemplu, în Levitic 16, Moise are sarcina de a-l instrui pe Aaron ca să nu intre în Cortul Sfânt oricând dorea și fără o pregătire prealabilă pentru că risca să moară (Levitic 16, 2), deoarece, locul respectiv, Sfânta Sfintelor, adăpostea chivotul Legii deasupra

${ }^{14}$ Cf. prof. dr. Al. Andriescu, prof. dr. Paul Miron (coord.), op. cit., p. 399.

${ }^{15}$ Cuviosul Eftimie Zigaben, Sfântul Nicodim Aghioritul, Psaltirea în tâlcuirile Sfinților Părinți, vol. II, transliterare, diortosire, revizuire după ediția grecească și note de Ștefan Voronca, Editura Egumenița, București, p. 728.

${ }^{16}$ John F. Walvoord, Roy B. Zuck (edd.), op. cit., p. 887.

${ }^{17}$ Cf. John Phillips, op. cit., p. 211.

${ }^{18}$ Ioan Vasile Botiza, Introducere în studiul Sfintei Scripturi, Editura Galaxia Gutenberg, Târgu-Lăpuș, 2005, p. 284. 
căruia YHWH își arăta slava. Interesantă este, aici, utilizarea unui termen ebraic, anume cuvântul „,kapporet", substantiv care, așa cum demonstrează cercetarea efectuată de Gordon Wenham asupra Leviticului, este probabil înrudit cu „,kipper”, care înseamnă „a face ispășire”, după cum sugerează și LXX atunci când folosește termenul „hilasterion” ${ }^{19}$. Wenham folosește $V g$ pentru a oferi ca echivalare a lui „,hilasterion” latinescul „propitiatorium”, derivat de la „propitio” cu sensul de „îndurare a divinității” care rezultă în urma sacrificiilor ${ }^{20}$.

O serie de bibliști, între care se disting autorii Comentariului cultural-istoric al Vechiului Testament, confirmă, la rândul lor, relativitatea acestei traduceri, pe care o consideră având „,un caracter speculativ" $^{21}$. Unii cercetători sunt înclinați să creadă că termenul este un împrumut din limba egipteană, unde însemna „loc de odihnă pentru picioare".

Însă, pentru cititorul Psalmului 139, ideea generală care se desprinde e aceea că aghiograful este cuprins de spaimă, de teamă în fața manifestării divine, adică tocmai în prezența lui YHWH, Care are un fel de ubicuitate, asemănătoare celei pe care o avea trupul înviat al lui Iisus, despre Care una dintre rugăciunile liturgice rostite de preot „în taină” ori de câte ori tămâiază cele patru colțuri ale Sfintei Mese din altar zice că era „,în mormânt cu trupul, în iad cu sufletul ca un Dumnezeu, pe cruce cu tâlharul și în rai, împreună cu Tatăl și cu Duhul, toate umplându-le ca Cel ce e de necuprins".

Din nou, dacă ne întoarcem la textul din Levitic 16, 2, observăm că, în fața slavei divine, spaima omului care se consideră mic și neînsemnat, deci neputincios în a privi pe Creatorul său, e o idee care, din perspectiva Vechiului Testament este un împrumut din akkadiană. Akkadienii foloseau termenul „melammu” pentru descrierea strălucirii divine vizibile. S-a mai sugerat că paralela lui

${ }^{19}$ Gordon Wenham, Leviticul, în seria CEXEL, traducere de Daniela Rusu, Editura Logos, Cluj-Napoca, 2004, p. 239.

${ }^{20} \mathrm{Cf}$. Cristian Bădiliță, Francisca Băltăceanu, Monica Broșteanu, Dan Slușanschi (coord.), ${ }^{* * *}$, Septuaginta, vol. I, Editura Polirom, Iași, 2004, p. 372.

${ }^{21}$ John H. Walton, Victor H. Matthews, Mark W. Chavalas (edd.), Comentariu cultural-istoric al Vechiului Testament, traducere de Silviu Tatu, Luca Crețan, Ramona Cuculea, Editura Casa Cărții, Oradea, 2014, p. 141. 
„melammu” în mitologia canaaneană ar fi termenul „anan”, același cu ebraicul folosit pentru descrierea substantivului ",nor" ${ }^{22}$.

Prin urmare, avem câteva argumente care pot să confirme ipoteza potrivit căreia, chiar dacă lexicul davidic are idei chaldeene, acestea ar fi putut fi inserate în textul cu pricina prin împrumut. Israeliții se învecinau cu aceste popoare și este foarte probabil ca unele cuvinte să fi fost folosite, îmbogățind lexicul ebraic. Dar, interesant este și faptul că noțiunile pe care le avem despre această terminologie nu se limitează strict la spațiul oriental, ele trecând și la pitagoreici, de exemplu, unde, așa-numitele „mistere eleusiene” au fost practicate continuând vechi tradiții. Un succes răsunător l-au avut misterele lui Isis. Norman Russel a cercetat amănunțit problema, și oferă diferite exemple despre rolul acestei terminologii în cultele de mistere.

Un exemplu este cel al lui Apuleius din Madaura care, în cartea a IX-a a „Metamorfozelor", considerate o lucrare de ficțiune, are la bază și o posibilă experiență senzorială a autorului, cum reiese din cea de-a XI-a carte. Despre ce este vorba? Isis, o zeitate egipteană elenizată, îl eliberează pe soțul său, Osiris, din lumea subpământeană, având capacitatea de a-i elibera și pe cei care o vor venera și care vor fi inițiați în misterele ei. Lucius, eroul romanului, după ce a trecut prin ritualul unui botez și a postit, pe timp de noapte este condus în partea cea mai lăuntrică a templului lui Isis unde afirmă că ,"a văzut soarele fulgerând cu strălucire luminoasă” și ,,s-a apropiat de zeii de sus și de zeii de jos și li s-a închinat față către față" ${ }^{23}$. Important este că, mai departe, după finalul ritualului de închinare, Lucius primește veșminte speciale și este prezentat în fața mulțimii adunate la intrarea templului sub forma unui Osiris, purtând „o cunună strălucitoare de palmier" cu frunzele aranjate ca niște raze. Privitorii socotesc că este ,împodobit precum soarele, și aranjat precum o statuie divină". Identificarea cu zeul, deși temporară, este completă.

Aici este cazul să ne oprim și să privim înapoi la v. 16 din Psalmul 139, pentru a face o conexiune între aceste idei, tipice istoriei religiilor, și hapax legomenon-ul „golem” despre care plecăm de

${ }^{22}$ Ibidem, p. 141.

${ }^{23}$ Norman Russel, Învățătura despre îndumnezeire în tradiția patristică greacă, traducere din limba engleză de Dragoș Dâscă, Editura Doxologia, Iași, 2015, p. 49. 
la ipoteza că ar fi o tipologie embrionară referitoare la Iisus Hristos. Într-o oarecare măsură am îndrăzni aici să afirmăm că linia hermeneutică este una profetică. Înainte de a ne raporta la mistica iudaică, esențială pentru înțelegerea utilizării acestei noțiuni, mai facem un mic popas terminologic. Intrebarea care răsare aici este următoarea: ar putea, de pildă, termenul grecesc „plasso” să fie echivalat $\mathrm{cu}$,golemul" iudaic?

Deși dificilă la prima vedere, chestiunea trebuie raportată la greaca Septuagintei. În Facerea 2, 2, forma de aorist pasiv a verbului „plasso" a devenit „eplasen”, cu sensul de „, a plăsmui”, imaginea directă fiind aceea a olarului care ia lutul pentru a modela o oală. În textul Facerii, verbul „plasso” apare de trei ori cu referire la om vv. 8, 15 și în v. 19 cu referire la crearea animalelor. La unii dintre comentatorii antici însă, verbul apare ca ceva ce vorbește despre o opoziție între „,omul făcut”, față de cel „,creat”, , plăsmuit”. Între acești comentatori, un loc de frunte îl ocupă Philon din Alexandria și, firește, Origen ${ }^{24}$.

Zice Philon: „Omul ceresc, fiindcă e făcut după chipul lui Dumnezeu, nu e părtaș la esența pieritoare și întru totul pământească; cel pământean, însă, a fost închegat dintr-o materie sfărâmicioasă pe care a numit-o țărână. De aceea și spune că omul ceresc n-a fost plămădit, ci că în el s-a întipărit, ca o pecete, chipul/id este icoana lui Dumnezeu și că celălalt, cel pământean, e plăsmuit, și nu născut de un creator" ${ }^{\prime 25}$.

Aici, doresc să mă opresc pentru a face niște lămuriri de ordin liturgic. În tipicul după care se oficiază slujbele în cultul ortodox, de exemplu, la Taina Sfântului Maslu, înainte de oficiul propriu-zis, tradiția cultică se raportează la un canon, adică o colecție de imne scurte, asemănătoare celei din slujba utreniei, cântată sau citită, după caz, dimineața, compusă din nouă cântări, după numărul celor nouă cete îngerești, așa cum sunt ele descrise de corpusul areopagitic, numit așa după paternitatea celui care se crede că le-a întocmit, Dionisie Areopagitul. Canonul de la Maslu are o istorie interesantă. Cel mai vechi manuscris care îl menționează este Sinai

${ }^{24} C f .{ }^{* * *}$, Septuaginta, vol. I, op. cit., pp. 56-57.

${ }^{25}$ Philon din Alexandria, Comentariu Alegoric al Legilor Sfinte după Lucrarea de Șase Zile, traducere, introducere și note de Zenaida Anamaria Luca, Editura Paideia, București, 2002, p. 41. 
97326. Atribuit lui Arsenie, arhiepiscopul Ciprului, în secolul al IX-lea, pentru a însoți ungerea bolnavilor cu untdelemn, din acest canon vreau să evidențiez aici prima strofă a cântării a VII-a: „Tu, Mântuitorule, Cel ce ești singurul Dumnezeu, Care cu mila și cu îndurările Tale tămăduiești tuturor patimile sufletelor și zdrobirile trupurilor, Însuți vindecă-l pe acesta ce pătimește în neputințe, tămăduindu-1"27.

Arsenie arhiepiscopul face o diferență între „patimi” care sunt în legătură cu sufletul și „,zdrobirile” puse în legătură cu trupul. Philon pare să urmeze aceeași distincție, atunci când zice că „omul ceresc" e părtaș la o esență/fire nepieritoare, pe când corporalul este supus unei materii sfărâmicioase, care ar putea fi analoagă „,zdrobirilor" corporale, tipice celor suferinzi, despre care vorbește textul liturgic întocmit de arhiepiscopul Arsenie.

Mai mult, Philon cunoaște faptul că materia plăsmuită ar fi acea esență descrisă de „ga-lam”, ceva nedefinit, fără o formă specifică, dar din care se poate modela, plăsmui ceva. Însă Philon vorbește despre o „pecete întipărită” de Creator în materia pe care a modelat-o.

Una dintre cele mai frumoase rugăciuni din anaforaua euharistică a Sfântului Vasile cel Mare zice: „....Stăpâne al tuturor, Doamne al cerului și al pământului și a toată făptura văzută și nevăzută, Cel ce șezi pe Tronul Slavei și privești adâncurile, Cel ce ești fără de început, nevăzut, neajuns, necuprins, neschimbat, Tatăl Domnului nostru Iisus Hristos, al marelui Dumnezeu și Mântuitorului nostru, nădejdea noastră, Care este chipul bunătății Tale, pecete asemenea chipului, Care întru Sine Te arată pe Tine, Tată, Cuvânt viu, Dumnezeu adevărat, înțelepciune mai înainte de veci, viață, sfințire, putere, Lumina cea adevărată..."28.

Reținem, în legătură cu tema, ca deosebit de importantă referirea la Iisus Hristos, Cel ce este nădejdea credincioșilor, chip/ icoană a bunătății (cf. Înțelepciunea lui Solomon 7, 26; Coloseni 1, 15:

\footnotetext{
${ }^{26}$ Paul Meyendorff, Taina Sfântului Maslu, traducere, prefață și note de Cezar Login, Editura Renașterea, Cluj-Napoca, 2011, p. 51.

27***, Molitfelnic, Editura IBMBOR, București, 2006, p. 131.

28 ***, Liturghier, Editura IBMO, București, 2012, pp. 247-248.
} 
icoană a Dumnezeului Celui nevăzut), „pecete” (cf. Ioan 6, 27); „Cuvânt viu" (cf. Evrei 4, 12) etc ${ }^{29}$.

Pentru ceea ce ne-am propus, interesantă este imaginea luată din literatura ioaneică a Noului Testament. Versetul 27 din cap. 6 din Ioan zice: lucrați nu pentru hrana cea pieritoare, ci pentru hrana care dăinuie spre viața cea veșnică, pe care v-o va da Fiul omului. Căci pe Acesta L-a pecetluit Tatăl, Dumnezeu.

Așa cum arăta și Cristian Bădiliță, în comentariul Evangheliei după $\operatorname{Ioan}^{30}$, putem să facem conexiuni între gândirea lui Philon și Evanghelia după Ioan. Punctul de legătură, în opinia eruditului patristician este lucrarea norvegianului P. Borgen, Bread from Heaven, Leyden, 1965. Plecând de la tratatele lui Philon, Borgen arată legăturile cu genul omiletic iudaic. Aici, mai arată Borgen, suntem în fața unui „midraș creștin” ${ }^{\prime 3}$. Rinaldo Fabris ${ }^{32}$ susține că cel de-al șaselea capitol al Evangheliei după Ioan poate fi numit „,al contestațiilor”, deoarece „nici o altă pagină evanghelică nu a suscitat atâtea discuții, ipoteze și interpretări precum cea care este prezentată astăzi în Evanghelia a patra sub forma dezbaterii dintre Isus și iudei cu privire la pâinea vieții" ${ }^{\prime 3}$. Pornindu-se, cel mai probabil, de la minunea înmulțirii pâinilor, descrisă la începutul acestui capitol, poporul evreu începea să vadă în persoana lui Iisus pe mult așteptatul „Mesia politic”, Cel care avea să izbăvească poporul din robia Romei. Speranța aceasta însă era veche.

Deja, odată cu Deuteronomul 18, 15-18 așteptarea mesianică se centrează în jurul unei figuri, chiar dacă într-un anume sens fără un contur și fără o formă anume, ale legislatorului și eliberatorului. Ajungem într-unul din punctele sensibile ale întregii chestiuni, pentru că, dacă privim doar din această perspectivă îngustă ideile

${ }^{29} \mathrm{O}$ hermeneutică a acestor texte biblice inserate în anaforaua euharistică a Sfântului Vasile cel Mare o face Ciprian Ioan Streza în teza doctorală intitulată Anaforaua Sfântului Vasile cel Mare. Istorie - text - analiză comparată, comentariu teologic, Editura Andreiana, Sibiu, 2009, p. 171.

${ }^{30} \mathrm{Cf}$. Noul Testament. Evanghelia după Ioan. Ediție bilingvă, traducere inedită și comentariu de Cristian Bădiliță, Editura Vremea, București, 2015, p. 237.

${ }^{31}$ Ibidem, p. 237.

${ }^{32}$ Rinaldo Fabris, Evanghelia după Sfântul Ioan. Traducere și comentariu, traducere din limba italiană de pr. Cristian Ungureanu, Editura Sapientia, Iași, 2016, p. 287.

${ }^{33}$ Ibidem, p. 287. 
despre Mesia în imaginarul iudaic, atunci hermeneutica are de suferit. Ideea este foarte apropiată celei a lui Calvin ${ }^{34}$ care, în comentariul Evangheliei după Ioan face anumite „,corecții”, atât interpretării lui Ilarie de Poitiers ${ }^{35}$, cât și Sfântului Chiril al Alexandriei sau lui Augustin. În opinia lui Calvin, acea pecete despre care vorbește autorul Evangheliei după Ioan nu reprezintă ,semnul întipărit și chipul viu al Tatălui Său. Căci El nu vorbește aici în mod subtil despre esența Sa veșnică, ci despre ceea ce i-a fost dat și poruncit, despre lucrarea Lui pentru noi și despre ceea ce trebuie noi să căutăm în El și să nădăjduim de la El”36. Chiar și abordarea părintelui Andrei Scrima pe acest subiect, unică în felul ei, se îndepărtează de noțiunea biblică a imaginii unei peceți. Părintele Scrima zice că pecetea despre care vorbește evanghelistul este, de fapt, pecetluirea faptei săvârșite de Iisus atunci când a înmulțit pâinile: „Tatăl a pecetluit fapta ce s-a săvârșit acum. A pecetluit fapta Fiului Său pentru că Fiul și-a săvârșit fapta întru Tatăl și cu Tatăl"37.

De ce este, însă, atât de importantă această noțiune de pecete pentru studiul de față? În primul rând, pentru că, în opinia noastră, este o imagine destul de reușită a noțiunii de golem. Dacă, așa cum se știe, golemul reprezintă o formă embrionară, o noțiune nedefinită, dar în curs de concretizare, la fel, pecetea, conferă o identitate, o autoritate, acolo unde ea a lipsit sau a fost ștearsă. Imaginea liturgică sau, mai bine zis, simbolul liturgic al acestui aspect este prescura folosită la oficierea Sfintei Liturghii. De ce? Chiar dacă poate apărea aici o filozofare lipsită de sens, totuși, dacă ne gândim mai profund, pe materia nedefinită, lipsită de formă a aluatului plămădit, la final i se conferă acestuia o autoritate prin folosirea unei peceți pătrate, care conține o referire la Iisus Hristos: IIS, HS, NI, KA. În traducere: Iisus Hristos, Biruitorul.

\footnotetext{
${ }^{34}$ Jean Calvin, Ioan. Comentariu, traducere în românește de Ștefan Gugura, Editura Logos, Cluj-Napoca, 2011.

${ }^{35}$ Hilarie de Poitiers, La Trinité, tom II (livres IV-VIII), texte critique par P. Smulders, traduction et notes par G. M. de Durand, Ch. Morel, et G. Pelland, în colecția "SCh", vol. 448, Cerf, 2000, p. 446.

${ }^{36}$ Jean Calvin, op. cit., p. 172.

${ }^{37}$ Andrei Scrima, Comentariu integral la Evanghelia după Ioan, traducere din arabă de Monica Broșteanu, traducere din franceză de Anca Manolescu, Editura Humanitas, București, 2008, p. 84.
} 
Aici se mai impune o precizare de ordin filologic. Rolul lui Iisus ca trimis al Tatălui este redat în textul ioaneic prin verbul

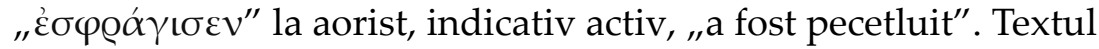
latin traduce „, $\varepsilon \sigma \varphi \varrho \alpha ́ \gamma\left\langle\sigma \varepsilon v^{\prime \prime}\right.$ folosind verbul la persoana a III-a, singular, la perfect, indicativ activ ",signavit”.

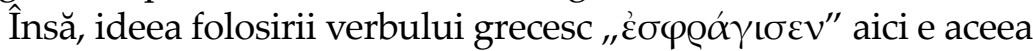
de a conferi autentificare, apartenență și ideea că respectiva persoană se află sub protecția divinității. Verbul mai apare și în Apocalipsă 7, 3-8 acolo unde, așa cum arată comentariul lui Savvas Agouridis $^{38}$, este pus în legătură cu „,cei aleși”. În Vechiul Testament, la profetul Iezechiel, în textele căruia apare frecvent imaginea lui Dumnezeu care este dispus să-Și reverse mânia. În Iezechiel 9, 4 Dumnezeu îi dă instrucțiuni unei persoane îmbrăcate în cămașă lungă până la călcâie, care avea peste mijloc cingătoarea, poruncindu-i: treci prin mijlocul Ierusalimului și pune semnul pe frunțile bărbaților care gem și suferă pentru toate nelegiuirile care se petrec în mijlocul lui. Semnul, gr. „,semion”, este, în ebraică, litera taw, ultima literă a alfabetului, care avea în vremea lui Iezechiel formă de cruce ${ }^{39}$. Litera taw este importantă și pentru că, în perioada lui Iov ea folosea ca semnătură ${ }^{40}$. Despre acest aspect ne confirmă însuși textul din Iov 31, 35-40: cine-mi va da pe cineva să mă asculte? De mâna Domnului dacă nu m-am înfricoșat și dacă înscrisul pe care l-am avut împotriva cuiva punându-mi-l pe umeri cunună l-am citit, și dacă nu l-am rupt, și nu l-am dat înapoi fără să iau nimic de la datornic, dacă pământul a gemut vreodată împotriva mea și dacă brazdele sale au plâns împreună, și dacă rodul lui l-am mâncat singur fără a plăti, și dacă sufletul stăpânului pământului l-am întristat luând de la el, atunci, în loc de grâu, urzică să-mi răsară, și pălămidă-n loc de orz. Și a încetat Iov să mai vorbească ${ }^{41}$.

Important pentru subiectul pe care mi l-am propus, în textul din Iov e că, stihul al II-lea din v. 35, în limba ebraică sună așa: „Acesta este taw-ul meu: Cel puternic să-mi răspundă”. Taw are și valoare de concluzie, fiind ultima literă a alfabetului ebraic. Expresia din Iov ar putea însemna: „Acesta este ultimul meu cuvânt”.

\footnotetext{
${ }^{38}$ Savvas Agouridis, Comentariu la Apocalipsă, traducere de pr. prof. dr. Constantin Coman, Editura Bizantină, București, 2004, p. 142.

39 ***, Septuaginta, Cristian Bădiliță, Francisca Băltăceanu și Monica Broșteanu (coord.), vol. 6/II, Editura Polirom, Iași, 2008, p. 76.

${ }^{40}$ John H. Walton, Victor H. Matthews, Mark W. Chavalas (edd.), op. cit., p. 748.

${ }^{41}$ Citat după Septuaginta, ediția de la Polirom, vol. 4/II, p. 116.
} 
În continuare am dori să facem corespondența cu textul din Isaia 53, 2. De fapt, pentru critica biblică, este vorba despre un text cunoscut sub numele de "cartea mângâierilor", din care fac parte fragmente, începând de la capitolul 40, 1 și terminându-se cu 55, 13.

Traducerea v. 2 este următoarea: Ca o mlădiță a crescut înaintea lui, ca o rădăcină în pământ uscat; fără frumusețe și strălucire ca să ne atragă privirile, și fără de înfățișare ca să ni-L facă drag.

Versetul face parte dintr-un capitol dedicat slujitorului lui YHWH „ebed YHWH”. Critica textuală vede aici chiar pe însuși profetul Dt-Is. Patristica, însă, vede altceva. Este vorba despre o aluzie clară la Iisus Hristos, despre Care un text paulin din Noul Testament afirma că S-a făcut „păcat”. Redau textul pentru a putea înțelege pe deplin sensul despre care vorbește Dt-Is. (citesc cap. 5 din II Corinteni).

Pentru a înțelege ideile pauline din II Corinteni 5 este necesară o privire mai amplă asupra textului acestei scrisori. Din moment ce Pavel, mai înainte fusese un prigonitor al creștinilor și acum își schimbase atitudinea, îndemnul său, adresat creștinilor din Corint, este acela că trupul fiecăruia, asemenea unui vas de lut nu va rămâne mereu așa. Comoara pe care au primit-o corintenii este Hristos. Vasul în care era depozitată comoara e un simbol al Apostolului Pavel și al lucrării sale de evanghelizare (cf. II Corinteni 4, 7-18). Aceasta nu înseamnă că vasul de lut va fi întotdeauna slab și pieritor: perspectiva finală este cea a transformării care va avea loc atunci când „locașul ceresc" va copleși cu viață natura muritoare a lui Pavel (cf. II Corinteni 5, 1-10). Deci, Apostolul arată că ar dori să fie pe placul lui Hristos, nu pe placul celor cărora le binevestește, cărora le slujește în calitate de trimis al lui Hristos, proclamându-le împăcarea și un nou început întemeiat pe jertfa lui Hristos pentru păcate ${ }^{42}$.

Apostolul Pavel este, prin urmare, o tipologie a lui Hristos. Ce legătură este, însă, între această imagine neotestamentară și golem? Cred că unul dintre cele mai interesante texte pe această temă este raportarea pe care o face Moshe Idel la golem, folosindu-se de imaginile biblice, de texte veterotestamentare în legătură cu Mesia.

${ }^{42}$ Cf. D.A. Carson, Douglas Moo, Introducere în Noul Testament, traducere de Dinu Moga, Editura Făclia, Oradea, 2007, p. 480. 
Așa cum, de pildă, un profet este un uns al Domnului, dar Iisus este „Unsul lui YHWH”, imaginea coborârii mirului pe capul lui Mesia duce cu gândul la coborârea ideilor sau a formelor de la Intelectul Agent în mintea profetului ${ }^{43}$. Mai mult: Moshe Idel oferă și un exemplu, în care face o combinație între gematria biblică și golem. El arată că, potrivit unor interpretări cabaliste, „legătura dintre trupul lui Mesia, intelectul lui și sursa intelecției corespunde celui de-al treilea rând de gematrii: ha-șem ha-gașmi (numele corporal) $=$ mașiah hașem (unsul numelui) $=$ ismah Moșe (Moise se va bucura $)=$ hamișa iețarim $($ cinci îndemnuri $)=703$. Primele trei expresii conțin consoanele $h$, ș, și $m$, fie în ha-șem (Dumnezeu, „Numele"), fie în moșe (Moise). Semnificația acestei prezențe este deosebit de clară într-un pasaj din lucrarea lui Abulafia Sefer haEdut: Moise L-a cunoscut pe Dumnezeu (ha-șem) cu ajutorul numelui (ha-șem), iar Dumnezeu (ha-șem), l-a cunoscut de asemenea pe Moise prin intermediul numelui (ha-șem). Cu alte cuvinte, $\mathrm{cu}$ ajutorul recitării numelui divin, Moise l-a cunoscut pe Dumnezeu și Dumnezeu l-a cunoscut pe Moise, sau Moise a devenit unsul lui Dumnezeu cu ajutorul numelui" ${ }^{44}$.

Putem aplica exemplul de mai sus în cazul textului profetic al lui Dt-Is: profetul este un delegat al lui YHWH, el vestește un mesaj prin care, el însuși este tipologia slujitorului lui YHWH, YHWH este cel care cunoaște în detaliu toate aspectele legate de profet, de viața sa, de cele lăuntrice ale sale și astfel, profetul devine o imagine, o întrupare, chiar poate o prefigurare a lui YHWH.

Insă, după cum afirmam, Biserica creștină a văzut în imaginea acestui slujitor pe Iisus Hristos, Mesia.

\section{Concluzii}

Apostolul Pavel Îl va descrie aproximativ în aceeași termeni de slujitor pe Hristos în Filipeni 2, 7: S-a deșertat pe Sine, chip de rob luând, făcându-Se asemenea oamenilor, și la înfățișare aflându-Se ca un om. Interesantă este utilizarea aici a ideii de „chip”, care ar fi, mai curând, tradus prin „formă”. Ideea este aceea că textul paulin sugerează

${ }^{43}$ Moshe Idel, Perfecțiuni care absorb. Cabala și interpretare, prefață de Harold Bloom, traducere de Horia Popescu, Editura Polirom, Iași, 2004, p. 363.

${ }^{44}$ Ibidem, p. 363. 
imaginea formei lui Hristos, Cel care a dorit de bunăvoie, așadar fără a fi silit de ceva sau de către cineva, să ia forma unui slujitor. Discuția cu privire la traducere, importantă pentru că ne ajută să înțelegem echivalarea cu textul deutero-isaianic, gravitează în jurul ideii de formă „morphe”. Pentru că uneori se sugerează ideea că avem un lexic redus, autorii de traduceri înclină balanța în favoarea utilizării unei formule standard, devenită tipică în toate expunerile teologice. Este vorba despre traducerea substantivului „morphe”, în acuzativ, feminin, singular pentru situația de față prin ideea de „chip". Chipul, însă, aduce mai degrabă ideea de „prosophon”, cu sensul „feței” cuiva. Or, dacă Hristos a luat doar „chip de rob" este cu totul diferit de ideea sugerată de „morphe”, o formă, idee plenară.

Spuneam că această raportare terminologică este importantă pentru că denotă ceea ce vrea psalmistul să exprime prin cuvântul golem. În ce fel? Dacă, de pildă, încercăm să punem cap la cap următoarele texte: Psalmi 139, 16, Dt-Is 53, 2, și textele pauline din II Corinteni 5, 21 și Filipeni 2, 7 vedem că ideea este aceea că, prin voia Tatălui, Iisus ia formă umană, Se întrupează, se face „hadamah", "trup de lut", lăsându-se modelat în pântecele Fecioarei, la fel ca orice embrion care începe de la o formă nedefinită și se dezvoltă.

Problema textului isaianic însă, e aceea că, în comparație cu majestatea divină, Iisus este, omenește vorbind, ca cineva neînsemnat, schimonosit, oricum, ca o persoană marginală.

Nu întâmplător, în Paremiar, care actualmente este introdus, contopit cu Triodul, de exemplu, la așa-numitele „,ceasuri împărătești", care poartă denumirea aceasta deoarece în timpul Imperiului Bizantin asista la celebrarea lor împăratul, textul isaianic este introdus, voit, cu referire la Hristos, care a luat, pentru a ne oferi mântuirea, forma unui rob. 